\title{
Т.И. Стексова
}

\section{Новосибирский государственный педагогический университет}

\section{Тенденция к «разорванности синтаксиса» на страницах современной прессы}

Изменению «языкового вкуса эпохи» в современной лингвистике посвящено достаточно много работ. Особенно этот процесс заметен на страницах современной прессы. Как отмечают лингвисты, наиболее подвержены изменению пласты лексики и фразеологии. Но этот процесс не обошел стороной и грамматическую систему русского языка, в частности, синтаксис.

По замечанию В.Г. Костомарова, «примеры свидетельствуют о том, что в синтаксисе новые процессы порой идут не менее активно, чем в лексике» [Костомаров, 1999, с. 247]. Исследователь отмечает такие явления, как сдвиги в управлении, экспансия предлогов, нарушение согласования, использование инфинитива в номинативной функции, нарушение правил глагольного управления и др. Он считает, что во многих случаях это - опечатки, корректорские оплошности, но растущая массовость не позволяет их просто игнорировать. Отмеченные им и другие явления из области синтаксиса представляют собой систему. Следовательно, необходимо попытаться объяснить возникновение этой системы, найти причины, породившие новые языковые факты.

Кроме уже отмеченных В.Г. Костомаровым фактов, хотелось бы обратить внимание на складывающуюся тенденцию на станицах современной прессы к такому явлению, которое условно назовем «разорванным синтаксисом». Истоки этого процесса намечались еще в 60-е годы XX столетия. И тогда впервые исследователи отмечали активизацию таких синтаксических явлений, как расчлененность высказываний приемами сегментации. По мнению Н.С. Валгиной, «на смену единому развернутому высказыванию с непрерывностью и последовательностью синтаксической связи, с вербально выраженными подчинительными отношениями приходит тип высказывания расчлененный, без ярко (словесно) выраженной синтаксической связи, с нарушением и прерыванием синтагматической цепочки» [Валгина, 2001, с. 186]. В широком понимании сегментация - это членение текста (высказывания) на отдельные «сегменты», при котором информация подается частями, порциями. Тематическая сегментация представлена именительным темы, рематическая сегментация - явлением парцелляции.

В современной прессе эти явления становятся настолько массовыми и разнообразными, что заставляют задуматься о расширении понятия парцелляции. Как известно, под парцелляцией понимается «способ речевого представления единой синтаксической структуры - предложения - несколькими коммуникативно самостоятельными единицами - фразами» [Русский язык, 1997, c. 328]. Явление парцелляции обычно связывают с коммуникативным аспектом синтаксиса, а именно со способом актуализации ремы высказывания. Парцелляцию, как и другие способы сегментации, относят к устно-разговорным экспрессивным синтаксическим моделям, которые сначала из обиходно-бытовой 
речи проникли в устную публичную речь, а в последние годы, как показывает языковой материал, заполонили и страницы прессы. Анализ двух еженедельников «Аргументы и факты» и «Литературная газета» показал следующее: в 5 номерах ЛГ (№ 24, 25, 26, 27, 30 за 2002 г.) встретилось 35 фрагментов текстов с использованием (причем неоднократным) парцелляции; в 3 номерах АиФ (№oo $26,27,35)$ - 21. Парцеллятами оказываются и отдельные слова (разные члены предложения) и словосочетания, и обособленные обороты, и присоединительные конструкции, и зависимые предикативные единицы. Частотны случаи, когда одна синтаксическая структура расчленяется на несколько парцеллированных структур. В подобных случаях происходит нагромождение парцеллятов, например: Прежде чем рассказать о профессионале, нужно вспомнить о любителях. Выпить и схалтурить. О фоне, на котором профессионализм хорошо заметен. Чтобы картина была полной и справедливой (АиФ на Оби. № 32, 2002 г.). Первый парцеллят - определения к слову любителях (любителях выпить и схалтурить). Вторая парцеллированная конструкция содержит объект предиката вспомнить с зависимой от этого объекта предикативной единицей (вспомнить о фоне, на котором...). И третья парцеллированная конструкция представляет собой придаточную предикативную единицу с семантикой цели (вспомнить, чтобы...). Итак, одна синтаксическая структура оказывается трижды разорванной и представленной четырьмя сегментами. Первая (базовая) конструкция является автосемантичной и не предсказывает обязательность наличия парцеллированных конструкций.

По мнению А.П. Сковородникова, парцеллированные конструкции в публицистике могут выполнять четыре функции: функцию актуального членения, функцию общей экспрессивизации (нерасчлененная эмоциональность, возбужденность), функцию усиления иронии и грамматико-конструктивную функцию [Сковородников, 1981]. Анализируемый нами языковой материал не укладывается в эту классификацию.

1. В ряде случаев парцеллированные конструкции используются «по назначению», для актуализации ремы: "Аня Казачкова не дождалась своего шестнадиатилетия, и день рождения отметили уже без нее. Через 10 дней после взрыва» (ЛГ, № 24-25, 2002 г.). Автору важно подчеркнуть, что жертвой террористического акта стала молодая девушка накануне своего дня рождения. Поэтому обстоятельство с временным значением становится рематичным и парцеллируется. Поэтому количество рематически значимых компонентов увеличивается, привлекая особое внимание читателя и воздействуя на него эмоционально.

«И сейчас тысячи других матерей в Израиле живут в страхе за своих детей. Но почему-то об этом мало пишут в мировой прессе. А порой даже наоборот - жалеют палестинцев. Тех самых, что радостно плясали на улицах, узнав о взрыве небоскребов Нью-Йорка. Тех самых, кто возводит головорезов и убийц в ранг святыху (ЛГ, № 24-25, 2002 г.). В данном фрагменте автор актуализирует внимание читателей на определениях - характеристиках палестинцев. Это достигается двойной парцелляцией и лексическим повтором. Данный прием помогает автору выразить субъективное восприятие палестинцев, выразить свою оценку происходящего. Как представляется, в этом примере наблюдается попытка воздействовать на читателя не только эмоционально, но и логически, путем подбора актуализируемых фактов. Актуализация рематических компонентов высказывания достигается не только делением высказывания на сегменты, лексическим повтором, но и синтаксическим параллелизмом сегментированных фрагментов: «Жертва аборта», позаимствовав у арабского беженца имя Ахмед и думая, что это и есть эквивалент имени человека вообще, нечто вроде христианского Адама, попал в клубок страстей конца 20 в. В мир, 
где нельзя играть с детьми, потому что тебя примут за педофила. Где нельзя высказать сентенцию, что мужчине нужен друг, потому что тебя примут за гомосексуалиста. Где нельзя жить на своей Родине, потому что там гражданская война, пытки, голод. Где паролем служит «убежище» и если ть его произнес, тебе дадут кофе и красивую куртку, но больше ничего не объяснят, не понимая, что ты - другой, думая, что все живут и обязаны жить по единственному закону, играть по единым правилам» (ЛГ, 2002, № 30).

2. Экспрессивно-динамическую функцию, т.е. использование парцеллятов для передачи эмоционального состояния говорящего можно продемонстрировать следующим примером из интервью Вл. Меньшова «Литературной газете»: «Я был свидетелем драки у Киевского вокзала, когда два азербайджанца били русского... При полном равнодушии толпь! Представить себе такого нельзя в Баку, чтобы два русских били азербайджанца! В Киргизии - нельзя! Чтобы два русских били киргиза! Клянусь вам, что с этого момента я считаю разговор об экстремизме провокацией! Самой настоящей! Продуманной! <..> С этого начинается фильм украинский, начиональный, который мы, русские, на кинофестиваль в Сочи берем на конкурсный показ! Мы, русские! В Сочи! Показываем! В конкурсе!» (ЛГ, 2002, № 27).

3. Иногда парцеллированные конструкции не несут дополнительной смысловой нагрузки, а используются для формального упрощения синтаксического построения. Это может происходить в том случае, когда исходная конструкция содержит в своем составе обобщающее слово, а ряд однородных членов очень сильно распространен. Сегментация текста не разрушает смысловую структуру, а лишь облегчает зрительное восприятие: «3a пять лет моей журналистской работы в Израиле я многое повидал и пережил: $u$ теракт на иерусалимском рынке вблизи нашего офиса, когда случайность спасла двух моих помощчнич, «опоздавщих» к взрыву на несколько минут. И стрельбу боевиков по жильм кварталам нового района Иерусалима - Гило. И теракты на главных улицах Тель-Авива, где всегда так многолюдно и где мы часто бывали по нашим журналистским надобностям» (ЛГ, 2002, № 24-25). По мнению А.П. Сковородникова, использование парцелляции без каких-либо экспрессивносемантических коннотаций характерно для научного стиля. Наши наблюдения доказывают, что парцелляция как средство снятия сложности структуры предложения используется и в публицистике.

4. Частотным и в то же время неожиданным становится использование парцеллятов в заголовках: «Профессия - агент. Литературный» (ЛГ, 2002, № 26); «Уличныхх продавиов - на зону. Торговую» (АиФ, 2003, № 14). Подобное использование представляется вполне удачным, так как нарушает ожидания читателя и тем самым привлекает особое внимание. Лексема агент вызывает ассоциацию с тайнами, шпионажем, чем-то секретным, что всегда привлекает читателя. Парцеллят литературный резко меняет направление мысли. Но внимание читателя уже привлечено, и есть вероятность, что он прочтет данный материал, хотя бы для того, чтобы расширить свои представления о профессии агента. Во втором примере заголовок без парцеллированного определения актуализирует то значение слова «зона», которое не зафиксировано в словаре Ожегова, но которое знакомо всем носителям русского языка: место содержания заключенных. В сочетании с лексемой продавцы лексема зона настраивает читателя на ожидание криминального сюжета статьи. Введение парцеллята торговую резко меняет направление мысли, но журналист уже достиг своей цели, внимание уже привлечено, и велика вероятность, что материал будет прочитан. Строго говоря, в подобных примерах рематичным является не сам парцеллированный элемент, а тот член предложения, от которого он оторван. Подобную функцию парцеллята, вероятно, можно было бы назвать 
провоцирующей.

5. Наши наблюдения показывают, что сегментирование текста может выполнять и текстообразующую функцию, участвуя в макетировании материала. Так, в АиФ № 262002 г. парцеллированная конструкция выступает в качестве подзаголовка, разбивая единую синтаксическую конструкцию (и смысловую!) на разные абзацы. Это оформляется графически и пунктуационно: «...уже в первыци день ММКФ сделал сразу несколько шагов.

Шаг назад...

...Во время церемонии открытия, когда власть перешла к дюжим охранникам, по собственным пристрастиям определявшим, кто достоин, а кто нет пройти по голубой дорожке». В этом абзаце идет речь и о других недостатках московского кинофестиваля. Следующий подзаголовок «Шаг вперед...» и первая конструкция этого абзаца, представляющая собой парцеллят первого предложения всей статьи, подводят читателя к восприятию положительных моментов фестиваля.

6. Парцеллированная конструкция в СМИ может так же, как и в художественном тексте, выполнять характерологическую функцию, служить средством создания несобственно-прямой речи: Представьте себе гражданина, который пришел в магазин и попросил наполнить пакет продуктами. В долг. С зарплаты отдаст (АиФ, № 27, 2002 г.). Парцелляты являются имитацией речи воображаемого персонажа.

7. Парцелляция может выполнять грамматико-семантическую функцию, выделяя заключительный член предложения в ряду однородных, выполняющий по отношению к остальным итогово-обобщающую функцию: Маленьких счастливчиков, которые пришли за руку с мамами и папами, ожидало еще множество сюрпризов и конкурсов: и для юных силачей, перетягивавших канат, и для сластен, кормивших друг друга мороженым. И, конечно же, море замечательных призов от спонсоров (АиФ, 2002, № 27). Последний член однородного ряда (ожидало множество сюрпризов, конкурсов, море призов) выделен в особую структуру для придания ему особой значимости.

Н.С. Валгина полагает, что тенденция к подобной расчлененности возросла именно под влиянием разговорной речи [2001]. Но нельзя не отметить влияния и художественной литературы, и научных текстов, так как функции парцелляции, характерные другим стилям, проявляются и в публицистических текстах. Публицистика легко «поддается влиянию», оказывается «всеядной».

Сегментация текста, на наш взгляд, не всегда получается оправданной и удачной. Так, совершенно неожиданным оказалось дистантное расположение сегмента от исходной синтаксической конструкции. Например: «Оказывается, известную во всем мире традиционную русскую водку определяет исключительно зерновой спирт (не картофельньй и не виноградный). Если мы положим в основу спирта не зерно, а рис - получится арака или сакэ, если сок гуавы - текила, если фрукть - сливовица или чача и т. д. Причем лучшие сорта водок всегда делались на основе ржаного спирта» (АиФ, 2002, № 27). Присоединительная конструкция явно связана с первым предложением: зерновой спирт, причем на основе ржаного спирта. Предложение, находящееся между ними, нарушает логику рассуждения и отвлекает внимание читателя. Если, по мысли автора, информация, изложенная в нем, представляется важной и необходимой, удачнее было бы представить ее в качестве вставной конструкции или поместить после присоединительной конструкции. Еще более неудачным представляется дистантное расположение сегмента в следующем примере: «Если все выведенные капиталы дружно вернутся в российскую экономику, она просто рухнет, не выдержав долларовой перегрузки. Экспорт замедлится, рынок заполнится дешевым импортом - для отечественной промышленности 
настанут тяжелье времена.

Во что вложить?

Поэтому разумнее говорить о постепенном возвращуении денег - 8 ближайшие три-пять лет. Причем неважно, какой именно капитал придет российский или иностраннылй» (АиФ, 2002, № 27). В данном примере логическая цепочка рассуждений (российская экономика рухнет, если все капиталы вернутся в экономику - поэтому нужен постепенный возврат) нарушена вставкой подзаголовка (Во что вложить?), который ни структурно, ни семантически оказывается не связанным с сегментированным высказыванием.

На наш взгляд, неоправданным является парцелляция зависимой предикативной единицы с семантикой уступки, тем более что парцеллят оказывается отделенным от базовой части абзацем:

«Думаю, что точка в вопросе статуса Севастополя - города русской морской славы - ещуе не поставлена.

Хотя официильно раздел Черноморского флота был завершен» (АиФ на Оби, 2002, № 28).

Надо заметить, что случаи парцелляции придаточных уступительных весьма частотны в современной прессе, хотя в пособиях по стилистике и литературному редактированию указывается на нежелательность или даже недопустимость этого.

Встречаются случаи употребления сегмента текста, который логически оказывается связанным не предыдущим предложением, a c пропущенным смысловым звеном. Рассмотрим подобный пример: «За последние лет двенадизать «серый» отток составил около 100 млрд. долларов. Хотя некоторые эксперты называют и вовсе фантастические ичфры - 300 и даже 500 млрд.» (АиФ, № 27, 2002 г.). Союз хотя, сигнализирующий о смысловых отношениях уступки, связывает не два рядом расположенных предложения, а последнее предложение с имплицитным смысловым звеном (я называю эту ичифру, которая кажется мне более достоверной, хотя...).

Подводя итог, хотелось бы отметить следующее: тенденция к разорванности синтаксиса в современной прессе свидетельствует о том, что парцелляция становится принципом реализации предложения, принадлежащим системе языка. Частотное и порой неуместное парцеллирование приводит к необходимости вносить коррективы либо в определение предложения, либо в систему синтаксических связей (так как утверждение о том, что синтаксические связи прерываются точкой в конце предложения, опровергаются речевой практикой), либо в определение точки как знака пунктуации, сигнализирующего о законченности предложения.

\section{Литература}

Валгина Н.С. Активные процессы в современном русском языке. М., 2001. Костомаров В.Г. Языковой вкус эпохи. М., 1999.

Сковородников А.П. Экспрессивные синтаксические конструкции современного русского литературного языка. Томск, 1981.

Русский язык. Энциклопедия. М., 1997. 